\title{
Women's Employment and Peripheralisation: the Case of Ireland's Branch Plant Economy
}

\author{
PROINNSIAS BREATHNACH, ${ }^{*}$ Maynooth, Ireland
}

\begin{abstract}
The mobilisation of reserves of unskilled women workers played a key role in the new international division of labour which emerged in the $1960 \mathrm{~s}$ and $1970 \mathrm{~s}$. This is illustrated in the case of the branch plant economy which emerged in the Republic of Ireland after 1960 . There has been rapid growth in female employment in the electrical engineering sector which is dominated by foreign firms. A case study of the electronics industry reveals strong gender segmentation and a heavy reliance on assembly work carried out mostly by women. High levels of trade union membership have had little impact on the inferior status of women in this industry. Dominance by foreign firms has created very limited employment opportunities for women at local level. The automation of assembly work, allied to plans to upgrade the status of branch plant activities in Ireland, will further restrict women's employment prospects.
\end{abstract}

\section{Introduction}

Although there has been some controversy over its interpretation (IFNKINS, 1984), the idea of a 'new' international division of labour (NIDL), distinctively different from the 'old' division between largely selfcontained industrial economies and primaryproducing peripheral economies, as classically identified by MARX (1961), had secured widespread acceptance in the literature on economic development by the end of the 1970s. While the diffusion of manufacturing production to low-cost underdeveloped countries has tended to be emphasised in the literature on the NIDL (FRÖBEL et al., 1980), in fact the phenomenon involved much more than this, and described a general process of international restructuring by transnational firms, whereby increasingly the individual operations in particular locations of these firms became integral components of inter-

\footnotetext{
* Department of Geography, St. Patrick's College, May-
} nooth, County Kildare, Ireland. national production systems. This process has affected both developed and underdeveloped economies, leading to a situation whereby national economic systems became increasingly truncated (HAYTER, 1982), while international production systems became increasingly integrated.

Among the complex of factors which contributed to the replacement of integrated national production systems by international integration were the desire to achieve economies of scale; the desire to exploit international variations in resource endowments and costs by locating segments of overall production systems in those locations most suited to those segments; and the desire to derive maximum advantage from international variations in taxation levels through the manipulation of intracorporate transfer prices (BRADBURY, 1985; BREATHNACH, 1989b). 'I he ability to exploit these various possibilities was, in turn, greatly facilitated by appropriate developments in corporate organisation, production technology, transport and communications (DICKEN, 1986). 
In the 1980 s, attention was increasingly focused on new forms of industrial restructuring, associated with a purported transition from the post-war 'Fordist' regime of accumulation to a new, post-Fordist regime of 'flexible' accumulation (GERTLER, 1988; ELSON, 1991). Growing flexibilisation has been observed in a wide range of areas, including forms of corporate organisation, production technology, functions of workers, and the hiring and firing of labour. This, in turn, is thought to be having an increasing impact on the locational patterns of manufacturing industry, arising from the growing trend towards the use of subcontracting and 'just-in-time' systems, and the replacement of human labour by new technology.

This paper outlines the growing incorporation of the Republic of Ireland into the NIDL in the 1960s and 1970 s, emphasising Ireland's role as a labour reservoir for transnational firms seeking a base for serving European markets. The particularly significant role of women workers in this process of branch plant industrialisation is detailed. This paper concludes with some observations on the outlook for women's employment in Irish-based industry arising from the impact of more recent forms of restructuring, allied to broader changes in the economic environment.

\section{Women and the NIDL}

Perhaps no aspect of the NIDL has been publicised as much as the role of women workers in transnational branch plants located in underdeveloped countries (ELSON and PEARSON, 1981; MITTER, 1986; PEARSON, 1986; FUENTES and EHRENEICH, 1987). Employed mainly in the textiles, clothing and electronics industries, women-mostly youngtypically account for around $85 \%$ of the workforce in the export processing zones in which many of these branch plants are located. Roughly 1 million people were employed in the 59 such zones which were operating in the Third World in 1980 (TAKEO, 1986; DICKEN, 1986).

The specific targeting of (especially young) women workers despite simultaneous high unemployment among the male workforce is conventionally attributed to a range of factors which make such workers particularly attractive to transnational firms. These include a keen eye for detailed work, manual dexter- ity, higher boredom thresholds than male workers, lower rates of pay for 'women's' work, and docile behavioural traits. Such characteristics are, in the main, derived from existing social structures emphasising female subordination and gender-specific social inculcation of particular skills. It is ironic that this informal inculcation of particular skills reduces greatly the formal training requirements of the types of work in question, thereby allowing such work to be designated 'unskilled' and therefore poorly paid.

Branch plants have a strong preference for recruiting young women with no previous formal work experience, particularly in an industrial environment. As KONIG (1975, p. 35) [quoted in PEARSON (1984)] puts it, such women are "virgins in terms of industrial employment that need not be retrained or untrained". A key element in this context is that young, inexperienced women tend to bring naive and docile attitudes with them into the workplace, thereby rendering them particularly amenable to patriarchal and authoritarian command structures. Any danger that these will be gradually replaced over time by greater cynicism or militancy is largely obviated by the fact that most of the women in question generally leave the workplace at an early age due to marriage, pregnancy or ill-health (the latter being a particularly common occurrence in Third World branch plants).

\section{The NIDL in Western Europe}

Apart from the relocation of production activities from industrial core regions to the Third World. much attention has also been paid to the role of women workers in the developing spatial division of labour within these core regions themselves (WOMEN AND GEOGRAPHY STUDY GROUP, 1984; MASSEY, 1984). In the European Community (EC), there has been a marked relative shift in manufacturing activity from core to peripheral regions over the last 20 years (KEEBLE et al., 1983: KNOX, 1984). Much of this has involved the relocation of production activity in search of reserves of cheaper labour (HUDSON, 1983), a strategy increasingly preferred to the alternative of attracting migrant peripheral labour to the core regions of the Community (PAINE, 1979). In addition, there is much evidence that inward investment from outside the EC, particularly from the U.S.A. and Japan. has also 
been opting for peripheral locations from which to serve the EC market (DICKEN, 1986).

Firms relocating to the EC periphery have been showing a strong preference for rural and small-town locations. While both men and women workers may be targeted in this context, a preference for women is frequently apparent, given the possibility of exploiting, on the factory floor, the traditionally subordinate position of women in such areas (HARRIS, 1983). In addition, the normally low participation rate of women in the labour force in rural areas means that their potential as a latent labour force is that much greater.

The same applies to women in declining industrial regions where male-dominant coalmining and heavy engineering had been the leading sectors. Such regions typically have had low female participation rates, thereby creating a potential labour reserve which is increasingly being drawn upon as women are forced into paid employment due to massive levels of redundancy among male workers. In these cases, the skilled work previously carried out by the menfolk is rapidly being replaced by 'unskilled' work done by women with little previous experience of industrial employment and frequently imbued with subordinate attitudes, given the 'macho' male culture which tends to be rampant in such regions. In some older industrial regions-especially where there is an existing tradition of female participation (such as textile regions) - there may be a preparedness to take on older women in the new factories, especially married women returning to work having reared their families (PEARSON, 1986; WICKHAM and MURRAY, 1987).

\section{Ireland and the NIDL}

Since the late 1950s, the Republic of Ireland (henceforth 'Ireland') has been pursuing an industrial policy which has been heavily dependent on the attraction of foreign investment. Tax breaks, capital grants and ready-built advance factories have been the principal formal incentives provided. There has been a gradual build-up in the stock of foreign firms in Ireland, with a marked acceleration immediately following accession to the EC in 1973, which allowed Ireland to be used as a low-cost base with duty-free access to the very large
EC market. This has been particularly attractive to U.S. investors, while there has also been a significant amount of investment since 1973 of Japanese origin (BREATHNACH, 1989a). The other main sources of overseas investment have been West Germany and the United Kingdom.

While there was a major slowdown in the inflow of foreign investment in the early 1980s, it has continued to grow, albeit gradually. With the previously heavily protected indigenous industrial sector suffering ongoing contraction in both the $1970 \mathrm{~s}$ and $1980 \mathrm{~s}$, employment in foreign manufacturing firms reached $43 \%$ of the total by 1989 (Industrial Development Authority Annual Report, 1989). More significantly, foreign firms now account for over two-thirds of manufacturing output and some $80 \%$ of non-food manufactured exports. This reflects the fact that foreign investment is mainly concentrated in expanding, high-technology sectors with above-average capital intensity, such as electronics, engineering and pharmaceuticals.

The types of plant located in Ireland by foreign firms point clearly to a subordinate, peripheral position within the NIDL (TELESIS CONSULTANCY GROUP, 1982; BREATHNACH, 1988, 1989b). These plants are mainly involved in export-oriented limited-skill assembly and testing operations with little associated research and development activity, and very restricted marketing and management functions. Material and service linkages with the Irish economy are weak, while linkages with overseas affiliates by contrast are quite strong, a situation which facilitates the manipulation of inter-affiliate transfer prices in order to concentrate profits in Ireland, where tax rates are effectively close to zero. This, in turn, helps to explain the high profitability of foreign firms in Ireland and the resultant high level of annual profit outflows: in 1989, these amounted to $10 \%$ of total GDP (Central Bank Quarterly Report, Spring 1990).

\section{Women's Employment and Foreign Investment in Ireland}

Apart from the formal incentives to foreign investment offered by the Irish government (low taxes, grants and factories), Ireland's status as a labour 
Table 1. Manufacturing employment change, 1961-1986*

\begin{tabular}{lccc}
\hline & $1961-1971$ & $1971-1981$ & $1981-1986$ \\
\hline All manufacturing & & & \\
$\%$ change, total & +21.0 & +11.5 & -9.6 \\
$\%$ change, males & +24.3 & +17.4 & -12.3 \\
$\%$ change, females & +14.2 & -2.0 & -2.3 \\
Textiles etc. & & & \\
$\%$ change, total & -0.2 & -28.7 & -19.9 \\
$\%$ change, males & 13.6 & 22.5 & -31.0 \\
$\%$ change, females & -2.9 & -33.3 & -10.1 \\
Metals and engineering & & & \\
$\%$ change, total & +54.9 & +81.0 & +6.7 \\
$\%$ change, males & +49.3 & +67.3 & +1.5 \\
$\%$ change. females & +81.9 & +135.2 & +21.3 \\
All excluding textiles cte. & & & \\
$\%$ change, total & +30.6 & +25.2 & -7.5 \\
$\%$ change. males & +29.2 & +24.9 & -10.1 \\
$\%$ change, females & +36.0 & +26.4 & +1.4 \\
\hline
\end{tabular}

"Source: Census of Population.

†Textiles etc. $=$ textiles, clothing, footwear.

reserve has also clearly acted as a significant attraction for overseas firms. High rates of fertility have produced annual additions to the labour force which the Irish economy has historically been unable to absorb, with the result that high levels of net emi gration have been a recurring feature of the Irish demographic experience (BREATHNACH and JACKSON, 1991). There has therefore been a virtually permanent labour surplus in Ireland, where wage costs are considerably below those obtaining in the core regions of the international capitalist economy.

Ireland's labour reserve status is further augmented by traditionally low rates of female participation in the labour force. This is related to the dominant position, until recently, of agriculture in the national economy, allied to the powerful role played by a highly-conservative and male-dominated Catholic Church in Irish society. This latter role is nowhere more clearly expressed than in the Irish constitution, enacted in 1937, which enshrined women's place as being in the home, and frowned on married women working elsewhere (O`DOWD. 1987). This was reinforced by legislation which restricted women's right to work, such as compulsory retirement upon marriage for women in the public service.

The female population in Ireland, therefore, includes a substantial latent reserve labour force which, as has been demonstrated by parallel situations elsewhere. presents significant recruitment possibilities to incoming industries, particularly as more liberal attitudes to women working, and accompanying legislative change, developed from the 1960s on. In 1961, when Ireland's policy of promoting inward investment was getting under way, only $26.4 \%$ of those in employment were women. The proportion in manufacturing employment was significantly higher, at $32.3 \%$, reflecting the fact that, at this stage, Irish manufacturing industry was principally concentrated in the major urban areas, especially Dublin (where female participation in the paid labour force is traditionally higher), and that the single largest industrial sector, in employment terms, was textiles and clothing. whose workforce (as elsewhere) is predominantly female.

\section{Manufacturing Employment Change in Ireland 1961-1986}

During the period 1961-1971, total manufacturing employment grew by $21 \%$ (Table 1), the bulk of this growth being due to incoming foreign investment (GILLMOR, 1985). While male employment grew at a faster rate than female employment in this period. this was due entirely to stagnation in the textiles and clothing sector. in which the majority of female 
manufacturing workers were to be found. Excluding this sector, female employment grew significantly faster than male employment $(36.0 \%$ as against $29.2 \%$ ). Of particular significance was the very rapid rate of growth of female employment $(81.9 \%$ as against $54.9 \%$ for males)-albeit from a very small base-in the metals and engineering sector (including electrical engineering), which has been the leading sector of foreign investment in Ireland.

The trends established in the 1960s were further reinforced in the 1970s. Heavy contraction in the textiles and clothing sector mainly affected women, so that aggregate female employment in manufacturing in the period actually declined slightly, despite an overall increase in employment in manufacturing of $11.5 \%$. Almost all of this increase was attributable to foreign firms (TELESIS CONSULTANCY GROUP, 1982). Excluding the textiles and clothing sector, however, female manufacturing employment grew at a slightly faster rate than for males. Again, the metals and engineering sector stands out in this regard, with female employment in this sector expanding by a massive $135.2 \%$, almost exactly double the rate for its male counterpart.

The 1980s have seen an overall decrease in manufacturing employment in Ireland, amounting to $9.6 \%$ in the period 1981-1986. To a certain extent this has been due to international recession in the early part of the decade, but the fact that output has continued to grow strongly through the decade suggests that other factors, particularly labour-saving technology and subcontracting of service functions (leading to a recategorisation of some workers from 'industry' to 'services' in official statistics), have been primarily responsible. The employment performance of females in the 1980s has been much stronger than that for males. Excluding textiles and clothing (which continued to contract rapidly), female manufacturing employment actually grew in 1981-1986, albeit slightly $(1.4 \%)$, whereas that for males fell sharply $(10.1 \%)$. In the metals and engineering sector, where there was an overall growth in employment, the number of female employees increased by $21.3 \%$ as against only $1.5 \%$ for males.

Most of the employment loss in the 1980s occurred in indigenous (largely 'traditional') industry, whereas there was only a slight decline in the foreign (largely 'modern') sector. Given the fact that almost half of the employment in foreign firms in Ireland is in the metals and engineering sector, as against only a fifth in the case of indigenous industry (Industrial Development Authority Annual Report, 1986), one can surmise-in the absence of aggregate data on the gender division in foreign and indigenous firms-that foreign firms have been primarily responsible for the superior manufacturing employment performance of women (apart from textiles and clothing) in Ireland since 1960 , and that these firms have therefore been much more oriented to the recruitment of women workers than have indigenous firms.

This conclusion is further supported by data on the spatial distribution of female manufacturing employment. Growth in female employment since 1961 has occurred exclusively outside the main urban centres. If one defines the latter as comprising Dublin City and County, Cork, Limerick and Waterford County Boroughs, and County Louth (which attracted a disproportionate share of manufacturing employment in the protectionist period prior to 1961), one finds that female manufacturing employment in these areas combined declined by $35.5 \%$ between 1961 and 1986 (due mainly to contraction of the textiles and clothing sector) while it increased by $139 \%$ in the remainder of the country. As a result, the proportion of total female employment located in the urban centres declined from 74.3 to $43.8 \%$.

The growth of female employment outside the main urban centres parallels the spatial pattern of growth in employment in foreign investment, which has shown a strong preference for rural and small-town locations (BREATHNACH, 1985). Of Ireland's nine planning regions, the three containing the highest proportions of manufacturing employment in foreign firms are all located in the traditionally less developed western part of the country (GILLMOR, 1982). These are also the three regions with the highest proportions of females in manufacturing (excluding textiles and clothing). American firms have played a particularly important role in shaping this pattern (Table 2). One may conclude, therefore, that access to female labour from a rural/small-town background has been a locational determinant of considerable significance to foreign firms investing in Ireland. 
Table 2. Regional distribution of foreign and female manufacturing employment, $1981^{*}$

\begin{tabular}{lccc}
\hline $\begin{array}{c}\text { Planning } \\
\text { region }\end{array}$ & $\begin{array}{c}\text { Females as \% } \\
\text { of manufacturing } \\
\text { employment }\end{array}$ & $\begin{array}{c}\text { Foreign firms as \% } \\
\text { of manufacturing } \\
\text { employment }\end{array}$ & $\begin{array}{c}\text { U.S. firms as \% } \\
\text { of manufacturing } \\
\text { employment }\end{array}$ \\
\hline Northwest & 31.5 & 47.2 & 22.6 \\
West & 29.1 & 48.3 & 36.7 \\
Midwest & 24.6 & 51.6 & 27.7 \\
Midlands & 23.6 & 36.0 & 18.9 \\
East & 22.9 & 30.1 & 8.7 \\
Donegal & 21.1 & 15.6 & 1.4 \\
Northeast & 19.6 & 37.0 & 19.7 \\
Southeast & 18.0 & 25.4 & 13.2 \\
Southwest & 16.2 & 36.8 & 14.4 \\
IRELAND & 21.8 & 34.4 & \\
\hline
\end{tabular}

*Sources: Census of Population (1981) and GILLMOR (1982).

$\uparrow$ Excluding textiles, clothing and footwear.

\section{Women's Employment in the Irish Electronics Industry}

As MASSEY (1984,p. 140) has noted, "Electronics is a labour-intensive industry-it is undisputed that the search for labour is one of the dominant determinants of its location." Given Ireland's labour-reserve status, therefore, one would expect that the electronics sector would be prominent among foreign firms which have located in the country, and this is indeed the case. In fact, electronics is the single most important element of foreign investment in Ireland, accounting for a sixth of all employment in foreign firms in 1987 , over $10 \%$ of total GDP, and about $20 \%$ of total exports. Foreign electronics firms account for $85 \%$ of all electronics employment in Ireland (COGAN, 1987). Production consists mainly of assembly and testing of intermediate (integrated circuits) and final products (especially computers). U.S. firms account for about $80 \%$ of employment in the foreign-owned electronics sector.

Two extensive studies of firms in the Irish electronics sector provide detailed insights into the gender dimension of employment in the sector. WICKHAM and MURRAY (1987) carried out surveys in both 1981 and 1983-1984 covering $90 \%$ of firms in the sector. JACKSON (1987) conducted a survey of larger foreign-owned electronics firms representing an estimated $84 \%$ of all employment in such firms. The following findings are largely derived from these studies.
Table 3. Occupational structure of the Irish electronics industry. $1983^{\circ}$

\begin{tabular}{lcc}
\hline & $\begin{array}{c}\text { Ocupational } \\
\text { category } \\
\text { as \%o of total } \\
\text { employment }\end{array}$ & $\begin{array}{c}\text { Women as \% of } \\
\text { occupational } \\
\text { category }\end{array}$ \\
\hline Managers & 6.1 & 3.0 \\
Professionalst & 7.3 & 15.5 \\
Administrators & 5.4 & 52.11 \\
Clerical & 7.5 & 74.9 \\
Supervisors & 5.5 & 20.2 \\
Technicians & 8.0 & 5.9 \\
Craft workers & 2.0 & 0.7 \\
Operatives & 55.4 & 74.1 \\
Others & 2.8 & 40.4 \\
Total & 100.0 & 53.4 \\
\hline
\end{tabular}

Source: WICKHAM (1986).

$\rightarrow$ Mainly engineers and technologists.

Women accounted for $53 \%$ of all employment in the sector in 1983-almost twice the participation rate of women in manufacturing employment as a whole. This high proportion of women is directly related to the high proportion $(55 \%)$ of the work force who were classified as assembly workers/operatives (Table 3 ). Of these workers, three-quarters were women, the proportion being higher for firms specialising in mass production of components and consumer products. Due to the low proportions of women in other work categories (apart from clerical work). over threequarters of all women in the electronics sector were assembly workers.

While the proportion of workers engaged in assembly 
work $(55 \%)$ is high by the standards of developed countries (a third in both the U.S. and the U.K. in 1980-1981), it is low by comparison with Third World export processing zones, where, typically, upwards of $90 \%$ of the workforce are assembly workers. This indicates that Irish-based electronics firms occupy an intermediate position in the industry's international division of labour. Thus, whereas developed core countries are oriented more towards management, marketing and technological development functions, and Third World countries specialise in component manufacture and assembly of simpler consumer products for re-export back to the country of origin, in Ireland there is a greater relative emphasis on testing and assembly of more complex electronic control systems, with products being sold on directly to European markets. Therefore, Irish-based electronics firms tend to employ higher proportions of technical, professional and sales staff than their Third World counterparts.

However, very few of these more highly-skilled workers are women. In 1983, only $3 \%$ of managers, $15.5 \%$ of professionals and $5.9 \%$ of technicians in the electronics sector were women (compared with 74\% of assembly workers) (Table 3). Thus is created a "rigidly hierarchical social system of production" (MASSEY, 1984, p. 140), whereby most of the executive, technical, scientific and skilled manual work is done by men, while the basic assembly work is mainly done by women. This apparent gender segmentation, however, does not necessarily reflect deliberate policy on the part of the firms in question; rather does it more likely reflect biases in the Irish educational and social systems which discourage women from seeking careers in these occupations. Thus, Catholic Church control of schools and widespread sex segregation in education have combined to steer female students away from technical and business subjects (BEALE, 1986; O'DOWD, 1987). As MASSEY (1984, p. 141) has observed: 'who does what job [in the electronics industry] is part and parcel of the reproduction of social structures in society as a whole".

Overt employment discrimination on gender grounds is illegal under Irish law. However, an appropriate supply of preferred female labour can be generated through more indirect means. Thus, the wage levels payable to electronics assembly workers are very low relative to the typical wages of male industrial workers, who therefore are deterred from taking on this work. At the same time, wages in the electronics sector are high compared to the average for female industrial (and unskilled service) workers, thereby stimulating a ready supply of women workers.

The relatively low wage rates received by women assembly workers in Irish electronics firms is further reinforced by very limited promotion outlets. Recruitment to more sophisticated job categories is usually done from outside the factory rather than from lower grades (and, as indicated already, involves mainly men). However, the evidence suggests that promotions which do occur from assembly work favour male workers, thereby reinforcing the notion that such work is essentially the preserve of women only.

\section{Women Workers and Trade Unions}

The fact that the great majority of assembly workers in Irish electronics firms are members of a trade union has had little impact on the status of the workers concerned. Trade union membership bears little relationship to trade union consciousness (MURRAY and WICKHAM, 1985). An important factor in this respect is that many foreign branch plants in Ireland have concluded exclusive deals-usually with the principal general workers union, SIPTU (previously the ITGWU)-in advance of setting up in Ireland. This means that trade union membership is a fait accompli for incoming assembly workers, and is something that is taken for granted, especially as union dues are normally deducted by management direct from wages and then passed on to the union. The tendency for wage rates and other conditions of employment in Ireland to be negotiated centrally at national level also inhibits the development of trade union identification among workers at local level.

For women workers specifically, interest in trade union affairs is further inhibited by the fact that union officials tend to be almost exclusively male (even where the vast majority of the workers whom they represent are women) and frequently unconsciously accept the notion that women workers per se should 
Table 4. Enployment structure of foreign-owned manulacturing plants in Linerick City

\begin{tabular}{|c|c|c|c|c|c|}
\hline \multirow[b]{2}{*}{ Work category } & \multirow[b]{2}{*}{$\begin{array}{l}\text { As } \% \text { of } \\
\text { all workers }\end{array}$} & \multicolumn{2}{|c|}{ Women } & \multicolumn{2}{|c|}{ Men } \\
\hline & & $\begin{array}{l}\text { As } \% \text { of } \\
\text { category }\end{array}$ & $\begin{array}{l}\text { As } \% \text { of } \\
\text { all women }\end{array}$ & $\begin{array}{l}\text { As \% of } \\
\text { category }\end{array}$ & $\begin{array}{l}\text { As } \% \text { of } \\
\text { all men }\end{array}$ \\
\hline Assembly/operative & 66.5 & 69.4 & 83.7 & 30.6 & 45.4 \\
\hline Technical/professional & 12.9 & 16.8 & 3.9 & 83.2 & 24.0 \\
\hline Clerical/mangerial & 15.6 & 4.3 .4 & 12.2 & 56.6 & 19.7 \\
\hline Maintenance & 5.0 & 1.9 & 0.2 & 98.1 & 10.9 \\
\hline Total & 100.0 & 55.2 & 100.0 & 44.8 & 10() .0 \\
\hline Total employment: 3131 & & & & & \\
\hline
\end{tabular}

not be paid as much as men, on the grounds that their income is essentially supplementary, whereas it is the role of male workers to earn the basic 'family' income. The low involvement of women in trade union activism-even where most of the workers are themselves women-may be attributed, if only in part, to obstacles placed in the way of such involvement, such as sexist behaviour and attitudes on the part of male trade union committee members and difficulty in attending after-hours meetings due to domestic duty commitments which still tend to fall disproportionately on women despite having jobs outside the home (HARRIS, 1983).

However, the main problem in this respect is that most women assembly workers show very little interest in any case in organising themselves in defence of their interests. As elsewhere, this may be related to the youth of electronics assembly workers, most of whom are recruited as a matter of policy direct from school or the state industrial training agency. Many of these may have little long-term commitment to their job, either because they hope to find something hetter or because they expect to retire on marriage--a practice which is still quite common (though declining) in Ireland. However, even the significant numbers of (mainly married) older women assembly workers show little inclination to militancy, either because of preoccupation with household duties, or because in many cases they are the sole or principal household income earners and do not wish to jeopardise their position, particularly as the range of employment choice open to working mothers tends to be spatially restricted by household encumbrances (WOMEN AND GEOGRAPHY STUDY GROUP, 1984).

\section{Women's Employment in Foreign Firms in Ire- land: the Local Impact}

Given the high proportion of manufacturing employment accounted for by foreign firms, particularly in the western regions, the distinctive gender structure of their workforces can have a significant impact on local labour markets. FLANAGAN (1986) conducted a study of the workforce structures of large foreign-owned branch plants in Limerick. Ireland's third largest city ( 1986 population, including suburbs: $74,000)$, located in the southwest of the country. Of eight such plants employing $100+$ workers, six cooperated in the study. Between them, these employed a total of 31.34 people (average 522); this represented $43 \%$ of all employment in manufacturing plants in the Limerick urban area in 1986.

Of the six firms, three were in electronics, two in electrical engineering, and one in precision mechanical engineering. Only the latter had a majority of male workers. Women represented $55 \%$ of the aggregate employment in the six firms, which is remarkably similar to the national figure for electronies workers reported above. Women workers in the six firms accounted for over half of all female workers in manufacturing plants in the Limerick urban area. thereby conferring on these firms a dominant role in the market for women industrial workers in the region.

Table 4 provides a detailed breakdown of the aggregate workforce in the six firms according to broad work categories. This shows that two-thirds of all workers in the six plants were assembly workers, most of whom were women. Given the low representation of women in the other work categories, this 
meant that over four-fifths of all women workers in the plants were in assembly. Women were particularly poorly represented in the technical/professional and maintenance (mainly skilled craft workers) grades. The available data did not allow a numerical distinction to be made between clerical and managerial workers, but the evidence from the Wickham and Murray and Jackson studies (above) suggests that women were more likely to be concentrated in the clerical end of this category.

These data, therefore, indicate, first of all, how the type of jobs available in the six factories is largely restricted to unskilled assembly work, and, secondly, how particularly circumscribed the labour market for women workers is in the plants. Given the dominant position of these plants in the local Limerick economy, this has major implications for the local labour market. In particular, a shortage of local outlets for growing numbers of technical/professional graduates will inevitably lead to emigration of these graduates from the region. The possibility that the Limerick situation is replicated around the country is strongly indicated by the rapid recent growth in emigration by technically-qualified people from the country altogether (BREATHNACH and JACKSON, 1991).

Analysis of the employment data for the six firms throws some interesting light on the phenomenon of gender segmentation, even within the unskilled work category. As already noted, the one firm engaged in mechanical engineering had a predominantly male workforce (including $80 \%$ of assembly workers), while the others-all engaged in electronics/electrical engineering-were predominantly female. In addition, gender segmentation was evident in the internal production operations of two of the latter firms. One electrical engineering firm had two categories of production worker-machine operators (almost 90\% male) and assembly workers (exclusively female). One can see clearly here the operation of conventional perceptions of what kinds of work are appropriate to men and women, even though the training and previous experience requirements of both kinds of work were broadly similar.

Finally, the six firms under study were asked to rate the importance of a range of possible factors (including availability of female labour) involved in choosing to locate in the Limerick area. The largest of the firms
(952 employees, of whom $63 \%$ were women) stated that the availability of female labour was of no importance, whereas availability of management and office personnel ( $5.5 \%$ of workers) was given as a very important locational factor. The second largest firm (59\% female) actually queried the inclusion of availability of female labour in the list. The firm with the highest proportion of women workers $(68.4 \%)$ listed all but four of the factors presented as being 'very important', thereby allocating no special importance to the female labour factor. A fourth firm, in which $51.5 \%$ of the workforce was female, marked all of the listed factors as being important except the availability of female labour, which was stated to be of no importance. Of the remaining firms, one was primarily a male employer; the other-the smallest of the six-did attribute importance to the female labour factor, but did not give it priority. Overall, one suspects a certain element of disingenuousness and perhaps sensitivity to the issue of female employment in the responses to this question.

\section{Conclusion}

Ireland has, over the last 30 years, developed as a base for supplying the European market with goods produced in branch plants of transnational firms. The reasons for locating in Ireland are complex, but access to relatively cheap, unskilled and female labour has clearly been of considerable importance. The emphasis on low-skill assembly work in branch plants located in Ireland, and the associated lack of higher-order functions, confers on Ireland a truncated and inferior form of development and therefore a dependent and subordinate position within the NIDL which emerged in the 1960s and 1970s. This position, however, is defined within a West European context: Ireland is not in the business of competing for the types of mobile investment which have in the past chosen to locate in parts of Southeast Asia and Latin America. Rather is Ireland's an intermediate 'semi-peripheral' status within the NIDL.

There is some evidence that foreign firms located in Ireland tend to upgrade their operations over time (WICKHAM and MURRAY, 1987); there is also evidence that the proportion of women entering higher-grade work is growing, albeit slowly and from a very low base. What is particularly worrying is that 
the repetitive assembly work in which women workers have hitherto been concentrated is precisely the kind of work most liable to automation with the development of micro-electronic technology. This process of replacement of unskilled and mainly female labour by new technology has been widely reported elsewhere (ELSON and PEARSON, 1989; PEARSON, 1989; ELSON, 1991), and could have profound repercussions on the spatial division of labour in manufacturing industry.

This replacement process is also clearly in operation in the case of Ireland, where growth in the number of assembly workers in the electronics industry in the 1980 s has been sluggish, while output has been expanding rapidly. Indeed, employment growth in the industry is now largely dependent on the continuous introduction of new firms. Whether this will continue in the context of growing competition from lower-cost locations in Southern and Eastern Europe, as the thrust towards European unity gathers pace, remains to be seen. As new European peripheries are created, the Industrial Development Authority is hopeful of raising Ireland's position in the pecking order of the European spatial division of labour, through upgrading the technical status of the functions being carried out there by foreign firms. Should this strategy prove successful, women workers will have to transcend traditional patterns of training and recruitment if they are to secure reasonable prospects of future employment growth in the manufacturing sector.

Acknowledgement-Gratitude is expressed to Peter Murray for his comments on an carlier version of this paper.

\section{References}

BEALE, J. (1986) Women in Ireland: Voices of Change. Macmillan, London.

BRADBURY, J. (1985) Regional and industrial restructuring processes in the new international division of labour, Prog. hum. Geogr. 9, 38-63.

BREATHNACH, P. (1985) Rural industrialisation in the West of Ireland, In: Industrialisation of the Countryside. pp. 173-195, M. Healey and B. Ilbery (Eds). Geo Books, Norwich.

BREATHNACH, P. (1988) Uneven development and capitalist peripheralisation: the case of Ireland. Anripode, 20, 122-141.

BREATHNACH, P. (1989a) Japanese manufacturing investment in the Republic of Ireland. Area, 21, 27-33.

BREATHNACH, P. (1989b) The new international div- ision of labour and Ireland, Paper to Conference of Irish Geographers, Dublin.

BREATHNACH, P. and JACKSON, J. (1991) Ireland, emigration, and the new international division of labour, In: Contemporary Irish Migration, pp. 1-10, R. King (Ed.). Geographical Society of Ireland, Trinity College, Dublin.

COGAN, J. (1987) New directions for Irish electronics. Technology Ireland, July/August, 25-28.

DICKEN, P. (1986) Global Shift. Harper \& Row, London.

ELSON, D. (1991) Appraising recent developments in the world market for nimble fingers: accumulation, regulation, organisation. Paper to International Workshop on 'Women Organising in the Process of Industrialisia. tion". Institute of Social Studies, The Hague.

ELSON. D. and PEARSON, R. (1981) Nimble fingers make cheap workers: an analysis of women's employment in Third World export manufacturing. Feminist Rev. 7, 87-1017

ELSON, D. and PEARSON, R. (1989) Introduction: nimble fingers and foreign investments, In Women's Employment and Multinationals in Europe, pp. 1-11. D. Elson and R. Pearson (Eds). Macmillan. London.

FLANAGAN, M. (1986) Foreign investment and the development of Irish industry, Unpublished BA dissertation. Department of Geography. St. Patrick's College. Maynooth.

FROBBEL. F.. HEINRICHS, J. and KREYE, O. (1980) The New International Division of Labour. Cambridge University Press. Cambridge.

FUENTES, A. and EHRENEICH, B. (1987) Women in the global factory. In: Intemational Capitalism and Industrial Restructuring, pp. 201-215, R. Peet (Ed.). Allen \& Unwin. Boston. MA.

GFRTIFR, M. S. (1988) The limits to flexihility: comments on the post-Fordist vision of production and its geography, Trans. Inst. Br. Geogr. 13, 419-342.

GILLMOR, D. A. (1982) Manufacturing Indusiry in the Republic of treland: Its Development and Distribation. Bank of Ireland. Dublin.

GILLMOR, D. A. (1985) Economic Activities in the Republic of Ireland. Gill \& Macmillan. Dublin.

HARRIS, L. (1983) Industrialisation, women and working class politics in the west of Ireland. Capital and Class. 9, $100-117$.

HAYIER, R. (1982) Truncation, the international firm, and regional policy, Area, 14, 277-282.

HUDSON, R. (1983) Regional labour reserves and industrialisation in the EEC, Area, 15, 22.3-230).

JACKSON. P. (1987) Irish women workers-their place in the global factory, Papes to Third Interdisciplinary Congress on Women. Dublin.

JENKINS, R. (1984) Divisions over the international division of labour, Capital and Class, 22, 28-57.

KEEBLE, D.. OWENS, P. L. and THOMPSON, $($. (1983) The urban-rural manufacturing shift in the European Community, Urban Stud., 20, 405-418.

KNOX. P. L. (1984) The Geography of Western Europe. (room Helm, London.

KONIG, W. (1975) Ton'ards an Evaluation of International Subcontracting Activities in Developing Countries: Report on Maquiladoras in Mexico. UNECLAM. Mexico City.

MARX. K. (1961) Capital. Vol. 1. Foreign Languages Publishing House, Moscow. 
MASSEY, D. (1984) Spatial Divisions of Labour. Macmillan, London.

MITTER, S. (1986) Common Fate, Common Bond: Women in the Global Economy. Pluto Press, London.

MURRAY, P. and WICKHAM, J. (1985) Women workers and bureaucratic control in Irish electronic factories, In: Restructuring Capital: Recession and Reorganisation in Industrial Society, pp. 179-199, H. Newby, J. Bujra, P. Littlewood. G. Rees and T. L. Rees (Eds). Macmillan, London.

O'DOWD, L. (1987) Church, state and women: the aftermath of partition, In: Gender in Irish Society, pp. 3-36, C. Curtin, P. Jackson and B. O'Connor (Eds). Galway University Press, Galway.

PAINE, S. (1979) Replacement of the West European migrant labour system by investment in the European periphery, In: Underdeveloped Europe, pp. 65-95, D. Seers, B. Schaffer and M. L. Kiljunen (Eds). The Harvester Press, Hassocks.

PEARSON, R. (1986) The greening of women's labour: multinational companies and their female workforce in the Third and in the First World, In: The Changing
Experience of Employment, K. Purcell (Ed.). Macmillan, London.

PEARSON, R. (1989) Women's employment and multinationals in the UK: restructuring and flexibility, In Women's Employment and Multinationals in Europe, pp. 12-37, D. Elson and R. Pearson (Eds). Macmillan, London.

TAKEO, T. (1986) Free trade zones in Southeast Asia, In: International Capitalism and Industrial Restructuring, pp. 280-287, R. Peet (Ed.). Allen \& Unwin, Boston, MA.

TELESIS CONSULTANCY GROUP (1982) A Review of Industrial Policy. National Economic and Social Council, Dublin.

WICKHAM, J. (1986) Trends in Employment and Skill in the Irish Electronics Industry. Department of Sociology, Trinity College, Dublin.

WICKHAM, J. and MURRAY, P. (1987) Women in the Irish Electronics Industry. Employment Equality Agency, Dublin.

WOMEN AND GEOGRAPHY STUDY GROUP (1984) Geography and Gender. Hutchinson, London. 